\title{
SUBSTITUTION DU BLÉ AU MAÏS DANS UN RÉGIME DE TYPE MAḮS-SOJA CHEZ LE PORC EN CROISSANCE-FINITION
}

\author{
M. LEUILlET et J. CASTAING* \\ Institut technique des Céréales et des Fourrages, \\ 8, avenue du président Wilson, Paris $16 \mathrm{e}$ \\ *Association générale des Producteurs de Mais
}

$64000 \mathrm{Pau}$

\section{RÉSUMÉ}

Un essai de substitution de blé au maïs a été effectué sur 96 porcs recevant leur aliment sous forme de farine humide. Des régimes comprenant, 38,77 ou 83 p. Ioo de blé sont comparés à un régime témoin exclusivement à base de maïs $(74 \mathrm{p}$. 100). Les aliments sont distribués selon le mode semi ad libitum jusqu'à un plafond de rationnement constant jusqu'à l'abattage.

Il ressort que le porc, dès le poids de $22 \mathrm{~kg}$, consomme normalement des régimes très riches en blé et les transforme avec la même efficacité que des régimes à base de maîs, dès lors que le taux de matières azotées brutes est de 18 p. Ioo et celui de lysine de $0,90 \mathrm{p}$. I00; le plafond de rationnement est à ce moment-là de 8 Ioo kcal d'énergie digestible par jour.

Une réduction des taux précédents jusqu'à $16 \mathrm{p}$. Ioo et $0,70 \mathrm{p}$. Ioo conduit aux mêmes performances avec un plafond de rationnement plus libéral, (8 $575 \mathrm{kcal}$ d'énergie digestible par jour).

\section{SUMMARY}

\author{
REPLACEMENT OF MAIZE BY WHEAT IN A MAIZE \\ SOYBEAN DIET OFFERED TO GROWING-FINISHING PIGS
}

Using 96 pigs, an attempt was made to substitute maize by wheat in rations offered in the form of moistened meal. Diets containing 38,77 or 83 p. Ioo wheat were compared with a control diet containing maize exclusively (74 p. 10o), given according to the semi ad libitum method. The maximum feed restriction level remained constant till slaughtering.

The results showed that the pig, from a weight of $22 \mathrm{~kg}$, ate very rich wheat diets and transformed them with the same efficiency as diets based on maize when the crude protein level was I 8 p. Ioo and the lysine level $0.90 \mathrm{p}$. Iоo. At this moment, the maximum feed restriction level was 8 roo kcal digestible energy per day.

Reduction of the previous levels till $16 \mathrm{p}$. Ioo and $0.7^{\circ} \mathrm{p}$. Ioo led to the same performances with a less restricted feeding schedule ( $8575 \mathrm{kcal}$ digestible energy per day). 